\title{
The internationalization of the Polish criminal law: how the Polish criminal law changed under the influence of globalization
}

\author{
Celina Nowak
}

Published online: 8 January 2013

(C) The Author(s) 2013. This article is published with open access at Springerlink.com

\begin{abstract}
Globalization changed the Polish criminal law. During the last 15 years the Polish criminal law has been transformed under the influence of globalization. The purpose of this study is to assess the extent and character of this process. The change was mainly a result of the implementation of legal instruments adopted by international organizations, to which Poland already belonged or aspired (European Union, Council of Europe, OECD, UN). This is what we can call the internationalisation of the Polish criminal law. Modifications affected many areas, in particular criminalisation. Definitions of certain existing offences were extended to cover interests which were not protected before (i.e. corruption offences). Also, new definitions were introduced (i.e. act of terrorist character). Additionally, other elements were changed. However, the impact of globalization on Polish criminal law goes beyond internationalisation. Certain criminalisations were introduced under the influence of foreign laws as a tool of fight against new types of crime, characteristic for the era of unification of cultural and social behaviours (e.g. stalking).
\end{abstract}

\section{Introduction}

On 6 June 2012 Poland celebrated the 15th anniversary of the adoption of the new Penal Code. ${ }^{1}$ This Code marks a transformation from a totalitarian state to a state

\footnotetext{
${ }^{1}$ Official Journal (“'O.J.”) No 88, item 553, entered into force on 1 September 1998. The Penal Code hereinafter also as "PC".

This article was elaborated on the basis of a paper presented during the 2012 W.G. Hart Legal Workshop "Globalisation, Criminal Law and Criminal Justice", organized by the Institute of Advanced Legal Studies. I would like to thank Professor Neil Boister for his most valuable comments that helped to improve this article. I am also very grateful to the anonymous reviewer.
}

C. Nowak $(\square)$

Kozminski University, Jagiellonska 57/59, 03-301 Warsaw, Poland

e-mail: cnowak@kozminski.edu.pl 
based on the rule of law. It is important to note that the transition that has taken place in Poland and other Central and Eastern European countries required a deep modification of respective legal systems. The change of regime was in fact a change of law [1]. In Poland, in 1997 the adoption of the new Penal Code, two months after the adoption of the new Constitution, was one of the supreme achievements in the process of democratization of the Polish legal system.

The provisions of the Code of 1997 were certainly in line with the principle of the rule of law. The Polish legislator confirmed the abolition of the death penalty. Also, certain institutions that dated back to the communist times ${ }^{2}$ or were a direct implementation of the Soviet criminal law, ${ }^{3}$ were then repealed.

As Poland was struggling to get rid of the legal remnants of the former regime, the intensity of globalization, understood here as 'growing interconnectedness of states of societies' and the 'progressive enmeshment of human communities with each other' [2] was increasing all over the world. Globalization is obviously not a new phenomenon but it certainly acquired a new dimension during the last 20 years, with the decline of the Soviet empire and later with increasing openness of China. The fall of the Berlin wall which enabled Poland to step onto the path of democratization, contributed to an unprecedented expansion of international business relations. Open borders allowed for easier flows of people and capital. The progress of science resulted in an expansion of new technologies, in particular in communication. However, the post-Cold War era has led to the emergence of new security threats, of transnational - if not global - dimension. It has become obvious that combating cross-border crime is not efficient without a coordinated action of more than one state. The traditional tools of international cooperation in criminal matters were not sufficient. It may be due to the fact that they were not flexible enough to combat new types of crimes or simply they were perceived as such by the states and international institutions and organizations. In any case, the growth of transnational crime [3] contributed to an intensified counteraction on the part of international community, which has received a new impetus with the progress of globalization. In the new security landscape the legislative activity of international and supranational organizations increased, many international instruments in international and transnational criminal law [4] as well as the EU law have been adopted. Considering substantive criminal law, in particular new types of behaviors have been directly or indirectly criminalized.

Interestingly, despite the fact that the work on the new Polish Penal Code coincided with the intensification of transnational cooperation, the Polish legislator originally almost completely ignored it. In particular, no notice was taken of new types of crimes which were already criminalized under international law or the criminalization of which was pending.

Obviously the Polish criminal law was influenced by international instruments. No legal system operates in a void, legal systems have always interacted. For instance, Polish criminal law after the 2nd World War was largely modeled after the Soviet Union criminal law [5]. After World War II the Polish legislator criminalized some of the core crimes, and later other "crimes against internationally protected interests" [6]

\footnotetext{
${ }^{2}$ Such as for instance reinforced protection of State owned economic entities.

${ }^{3}$ Such as e.g. aggravated punishment for perpetrators of so-called hooligan offences used to prosecute political opposition.
} 
(e.g. organized crime, drug offences - regulated in a separate act). However, the only new type of crime penalized in the Polish criminal law in the 90s under the influence of transnational criminal law ${ }^{4}$ and the EU law ${ }^{5}$ was money laundering. It was introduced into the Polish law first in 1994, and then included in the new Penal Code in $1997 .{ }^{6}$ Otherwise, no new 'globalized' types of crime were added to the Polish law.

The real transformation of Polish criminal law started after the 1997 Penal Code had been adopted. It may be due to two phenomena, both inspired by globalization: the internationalization and modernization of law.

Although Poland was already a member of the United Nations, after 1989 it aspired for membership in other Western international political and economical organizations such as the European Union, Council of Europe, OECD. The conditions of membership embraced the adjustment of law, which required a great effort of harmonizing Polish legislation with supranational provisions of these international bodies. Thus, a dramatic change of Polish criminal law is the result of the process of implementation of international instruments that started around the year 2000 and referred to international and transnational criminal law, as well as the EU law. That process may be called the internationalization of the Polish criminal law.

However, the impact of globalization on the Polish criminal law goes beyond internationalization. Globalization certainly has an extra-legal dimension and leads to cultural and social (behavioral) unification which, in turn, generates similar types of behaviors in different countries, particularly related to the progress of new technologies. Some of these behaviors are subsequently qualified as criminal offences. There is no harmonized supranational legislation in this area but evidently provisions adopted in one national system affect other systems. The harmonization of domestic criminal solutions in this respect takes place on a different basis, not within the internationalization, when the model legal norm comes from an international convention or a supranational legal act, but through a spontaneous horizontal diffusion of legal norms [7] between legal systems. Also Poland has experienced a change of criminal legislation within this context. The process in question may be called the modernization of law. The two processes: internationalization and modernization can complement each other, contributing to widening of the scope of criminalization.

The purpose of this study is to assess the extent and character of the transformation of the Polish substantive criminal law due to globalization after the adoption of the 1997 Penal Code $^{7}$ (globalization influenced Polish criminal procedure as well, in

\footnotetext{
${ }^{4}$ In particular the 1988 United Nations Convention against Illicit Traffic in Narcotic Drugs and Psychotropic Substances, which Poland signed on 6 March 1989 and ratified on 26 May 1994.

${ }^{5}$ Art. 85 of the Europe Agreement of 16 December 1991 establishing an association between the European Communities and their Member States, of the one part, and the Republic of Poland, of the other part obliged Poland to make every effort and cooperating in order to prevent the use of their financial systems for laundering of proceeds from criminal activities in general and drug offences in particular. It was further stated that the cooperation in this area will include administrative and technical assistance with the purpose of establishing suitable standards against money laundering equivalent to those adopted by the Community and international fora in this field, in particular the Financial Action Task Force (FATF).

${ }^{6}$ Art. 299 of the 1997 Penal Code.

${ }^{7}$ For this reason the article does not address the implementation of anti-money laundering standards, which started before the adoption of the 1997 PC. However, it should be noted that Polish provisions in this respect are not fully in line with international law. For details see e.g. [9].
} 
particular forms of international cooperation in criminal matters [8]). It should be noted, though, that modifications affected so many areas that it would be impossible to present all of them. I will therefore focus on the most distinctive amendments. I will discuss first the impact of transnational criminal law, international criminal law and the EU law on Polish law, and present the changes referring to the rules of responsibility for committing offences (2), rules of jurisdiction (3) and criminalization (4). Then I will briefly touch upon the issue of modernization of Polish criminal law (5). Finally, I will draw more general conclusions referring to the characteristics of internationalization in the context of the Polish criminal law (6).

\section{Changes referring to the rules of responsibility}

The harmonization of Polish criminal law with supranational instruments required amongst others - a change of rules of responsibility or more particularly - an extension of the personal scope of responsibility for committing criminal offences.

It is true that most of international instruments do not contain detailed provisions referring to the general part of the criminal law [10]. They impose on the member states obligations to provide for responsibility of instigators, aiders and abettors, or referring to inchoate offences, but specific rules and forms of responsibility are left to the decision of the national legislators. On the other hand, certain international legal instruments do include provisions on specific principles of responsibility for offences provided therein and therefore may affect the national criminal law. As regards the Polish criminal law, Poland in particular ratified the Statute of International Criminal Court (also as "ICC") ${ }^{8}$ which provides for a particular model of individual criminal responsibility as well as responsibility of commanders and other superiors (Art. 28). Poland also recognizes and cooperates with ad hoc international criminal courts [11]. Certain legal doctrines used in the case-law of these courts (such as joint legal enterprise [12]) are unknown to the Polish criminal law. And yet these may have at least an indirect impact on the Polish legal system and contribute to an extension of the Polish model of responsibility for commission of offences.

This is already taking place with regard to the Statute of the ICC. In 2010, within a framework of a series of amendments aimed at harmonization of the Polish law with the Statute, a new type of offence was included into the special part of the Penal Code (Art. 126b). It provides for responsibility of a person who in breach of his duty of due control allows for commission of an offence constituting one of the core crimes, criminalized in the Polish Penal Code, by a person under his effective authority or control, intentionally as well as unintentionally. The provision in question refers both to military and non-military commanders.

Commanders are therefore treated as perpetrators of a specific offence described in the special part of the PC, while no general rule on individual criminal responsibility through command responsibility [13] was introduced. On the other hand, when it comes to sanctions for intentional command responsibility, the PC refers to provisions on core crimes. This may suggest that this type of responsibility is not an

\footnotetext{
${ }_{8}^{8}$ Poland signed the Statute on 9 April 1999 and ratified it on 12 November 2001, with the effect from 1 July 2002. The Polish official text of the Statute was published in O.J. 2003, No 78, item 708.
} 
autonomous offence, but in fact a form of specific perpetration. And yet, general paradigm of responsibility of individuals for perpetration of criminal offences has remained unchanged and no public discussion on this issue has been held. Possible difficulties with regard to interpretation of this new provision will have to be addressed in the light of Art. 28 of the Statute [14].

Also, it seems interesting to point out that an obligation to implement international instruments compelled Polish legislator to introduce a type of corporate liability for offences. The issue was controversial as historically the Polish legal system did not recognize the criminal liability of legal persons. There were drafts which proposed the introduction of the penal responsibility of legal persons directly to the Penal Code. However, eventually, it was decided to apply a less radical solution. In 2002 a separate statute ${ }^{9}$ was adopted which provided for liability of so-called collective entities for acts prohibited under penalty. It was conceived as a specific type of liability, not of criminal character. As the liability of legal persons is designed as quasi-criminal, the issue does not fall within the scope of this article. ${ }^{10}$

\section{Extended jurisdiction}

Traditionally the Polish criminal jurisdiction was based on typical principles, such as the principle of territoriality and principle of active and passive nationality (with a requirement of double criminality). Universal jurisdiction was also recognized [16].

However, the internationalization of the Polish criminal law required an extension of jurisdiction. Therefore, Poland expanded its criminal jurisdiction to enable it to prosecute and punish perpetrators of three new categories of acts. Firstly, Poland has jurisdiction over acts of a terrorist character committed abroad by a foreigner (provided the requirement of double criminality is fulfilled), ${ }^{11}$ which was to fulfill the requirements coming from the 2002 EU Framework Decision on combating terrorism. This solution is not devoid of doubts. Some authors justly argue that it is not necessary as terrorism is anyhow prosecuted on the basis of the principle of

\footnotetext{
${ }^{9}$ Act on Liability of Collective Entities for Acts Prohibited under Penalty, published in O.J. No 197, item 1661 as amended.

${ }^{10}$ It should be noted that the liability of legal persons is restricted to the commission of certain types of offences only. The list includes offences typically related to activities of corporations, in particular economic offences. Also, the liability is based on a two-step model. First, penal responsibility of an individual who was linked to the collective entity and acted to its benefit must be recognized in a valid and final conviction or a decision otherwise terminating the proceedings (such as e.g. conditional discontinuance of proceedings). A corporation may only be held liable if there was no due diligence in choosing the person who later committed the act (culpa in eligendo) or this person was not supervised properly (culpa in custodiendo), or the company was not organized well enough to avoid commission of the act (socalled 'organizational fault'). The liability of collective entities is therefore not autonomous, as the liability of an individual constitutes a prerequisite to proceedings against a collective entity. The choice of such a legal structure makes the model of liability of legal persons unnecessarily complicated. Doubts have been raised that this model may seriously hinder effective prosecution of collective entities (OECD even recommended to change the model - see [15]. In fact, only 50 legal persons have been convicted in Poland for commission of a prohibited act so far (years 2006-2011, statistical data of the National Criminal Register). The convictions referred to minor tax offences. In this respect then, the change induced by globalization is only superficial in the sense that it has not been effectively implemented in practice.

${ }^{11}$ The notion of an 'act of terrorist character' is explained below.
} 
universal jurisdiction (and does not require the double criminality condition to be fulfilled [17]).

Secondly, Polish jurisdiction extends to criminal acts which have allowed any person to achieve a material benefit on the Polish territory, even indirectly. This rule does not depend upon the nationality of perpetrator or criminal law rules in force in the place of commission of the offence. This provision was said to implement a requirement set forth in Art. 4(1) of the PIF Convention of $1995^{12}$ [18]. However, in fact this provision does not make any reference to the offences defined in this Convention and extends Polish jurisdiction to any offence which allowed to achieve material benefit in Poland. This rule should be criticized as too wide - it refers to any type of offence, any type of material benefit, any person (not only perpetrator of an offence but also third parties [19]). It seems that in this regard Polish jurisdiction would be impossible to enforce.

Third, the Polish universal jurisdiction principle was also subject to modifications. Before the internationalization, pursuant to Art. 113 PC, notwithstanding regulations in force in the place of commission of the offence, the Polish criminal law was applied to a Polish citizen or a foreigner, with respect to whom no decision on extradition has been taken, in the case of the commission abroad of an offence which the Republic of Poland is obligated to prosecute under international agreements. This was an implementation of the aut dedere aut iudicare rule. In $2010,{ }^{13}$ an additional clause was added to this provision in order to cover explicitly crimes defined in the Rome Statue of the International Criminal Court. A draft proposal was submitted to the Parliament by the Polish government which explained that it was necessary as only the International Criminal Court has jurisdiction over core crimes. Therefore, under the unamended Art. 113 Poland would not be able to prosecute its citizens who committed such crimes abroad unless the double criminality requirement was fulfilled. The Parliament shared this view, the provisions have been changed and at present Poland may prosecute and punish perpetrators of all of the core crimes, Polish citizens included, irrespective of criminalization of their actions in the place of commission of the criminal act (and if the perpetrator is not a Polish national - provided that he has not been extradited [20]).

\section{Extension of criminalization}

The special part of the Penal Code has been most affected by transformation brought about by globalization, in particular by internationalization. As a result of the process of harmonization of Polish criminal law with supranational regulations, some definitions of certain existing offences were extended to cover interests which previously were not protected. Additionally, new types of offences were criminalized.

\footnotetext{
12 This provision stipulates as follows: "1. Each Member State shall take the necessary measures to establish its jurisdiction over the offences it has established in accordance with Article 1 and 2 (1) when: fraud, participation in fraud or attempted fraud affecting the European Communities' financial interests is committed in whole or in part within its territory, including fraud for which the benefit was obtained in that territory,...".

${ }^{13}$ Act of 20 May 2010, entered into force on 8 September 2010, O.J. No 98, item 626.
} 
Implementation of suppression conventions and European Union law

\section{Criminalization of corruption}

Probably the most notable change refers to the criminalization of corruption. Traditionally, ever since the 1930s, only three types of corruption offences were criminalized in Polish criminal law: active and passive corruption in the public sector (bribery of public officials) and passive trading in influence [21].

Since the year 2000 the Polish legislator has been faced with a unique challenge. It had to modify criminal law in order to harmonize it with numerous anti-corruption legal international instruments. ${ }^{14}$ The substantive scope of these regulations varies. The obligations provided therein are different, even the definitions of crimes, which are called the same, are diverse. The Polish legislator was forced to accommodate these differences within one Penal Code. The task was difficult and it is questionable if it was successful. It is clear however that the internationalization contributed to a large extension of the existing scope of criminalization. On the one hand, the personal scope was modified. Firstly, a new group of individuals who may be held liable for corruption offences was added. Secondly, the liability of legal persons for corruptive offences was provided for in the specific statute mentioned above. On the other hand, new types of corruptive behaviors were criminalized, in particular active trading in influence and private sector corruption.

In regard to the expansion of responsibility to this new group of individuals for commission of corruption, it helps at the outset to explain that according to the Polish law, bribery in the public sector may only be committed by a person performing a public function. Initially, historically speaking, the notion of 'performing a public function' was elaborated in the case-law. Only the notion of 'public official' was defined in the Code, and the Supreme Court confirmed as early as in 1970, that the term 'person performing a public function' was wider than the term 'public official' [22]. Therefore, in case of a corruptive behavior the court was called to decide whether a given person performed a public function and might have been prosecuted on those grounds.

The change due to internationalization consisted in the introduction of the responsibility of a group that may in short be called 'foreign public officials' but in fact encompasses two categories of individuals. Firstly, persons performing a public function in a foreign state, and secondly, persons performing a public function in an international organization. Pursuant to special assimilation clauses, introduced into the Penal Code in 2000, ${ }^{15}$ individuals belonging to either of these groups may be subject to a penalty on the same terms as the persons performing a public function in Poland [23]. The concept of 'performing a public function' in a foreign state or

\footnotetext{
14 The conventions were as follows: 1st Protocol to the PIF Convention of 27 September 1996; Convention on the fight against corruption involving officials of the European Communities or officials of Member States of the European Union of 27 May 1997; OECD Convention on Combating Bribery of Foreign Public Officials in International Business Transactions of 21 November 1997; and the Council of Europe Criminal Law Convention on corruption of 27 January 1999. Later there was also a need to implement the Council of the EU's Framework Decision 2003/568/JHA of 22 July 2003 on combating corruption in the private sector and the UN Convention against corruption of 31 October 2003 ("UNCAC").

${ }^{15}$ Act of 9 September 2000, O.J. No 93, item 1027, entered into force on 4 February 2001.
} 
international organization was again not explained in the law. It should be pointed out that the Polish law penalizes both active and passive bribery of foreign public officials, in this way fulfilling the obligations resulting not only from the 1997 OECD Convention and the 2003 UNCAC (Art. 16), but in particular the 1999 Council of Europe Convention (Art. 5 in relation to Art. 2 and 3).

Since the undefined notion of "persons performing a public function" had led to differences in interpretation, in 2003 the Polish legislator adopted its statutory definition clarifying that a person performing a public function is a public official, a member of the local government authority, a person employed in an organizational unit which has access to public funds, unless this person performs exclusively service type work, as well as another person whose rights and obligations within the scope of public activity are defined or recognized by a law or an international agreement binding for the Republic of Poland. This definition, which was elaborated both to fulfill the requirements coming from the Supreme Court's case-law and anti-corruption international instruments, in particular the OECD Convention [24], gives raise to many doubts [25]. It may be questionable as it relates the performance of a public function not with the public character of competencies of the person concerned but with the sole fact of his/her employment in an entity using pubic funds. This provision extends the notion of performing a public function to categories of individuals which in reality do not have anything to do with a public function or even further - with the public sector. The application of this definition to transnational cases might lead to surprising results, as persons who are not recognized as public officials by their states could be covered.

Also, as mentioned above, new types of corruptive behaviors were criminalized under the influence of supranational law. In 2003, an active form of trading in influence, meaning buying someone's influence over the decision process involving a third party (person or institution of a public sector), was criminalized. In addition, Poland undertook an effort to criminalize bribery in the private sector. This endeavor has not been fully successful. At the beginning the criminalization referred to active and passive corruption committed by or in relation with a person holding a high position only (eg. CEO, manager) within a business entity, notwithstanding if it was an entity operating in a private or public sector. This solution was controversial [26], as the supranational instruments requiring criminalization of private sector corruption ${ }^{16}$ provided for a much wider definition of perpetrator. Eventually, following a recent amendment to the Penal Code, ${ }^{17}$ the provision was changed, and currently any person working for a business entity may be held liable for this offence, which is a positive change.

However, the criminalization is still limited to acts which are related to a distortion of competition or likely to cause damage to the business entity [27]. It seems that when the Polish legislator was preparing the draft law to criminalize private sector corruption, it took as a model the provisions of the only instrument in force at the time, i.e. the Joint Action of 22 December 1998 on corruption in the private sector. ${ }^{18}$ It allowed national legislators to restrict the definition of private sector bribery to

\footnotetext{
${ }^{16}$ In particular Council Framework Decision 2003/568/JHA of 22 July 2003 on combating corruption in the private sector and Council of Europe Criminal Law Convention on corruption of 1999.

${ }^{17}$ Act of 24 October 2008, O.J. No 214, item 1344, came into force on 18 December 2008.

${ }^{18}$ A non-binding instrument adopted within the III pillar of the EU, 98/742/JHA.
} 
conducts which involve, or could involve, the distortion of competition, as a minimum within the common market, and which result, or might result, in economic damage to others by the improper award or improper execution of a contract. ${ }^{19}$ The Polish legislator narrowed the adopted definition of private sector corruption accordingly. It did not take into account that a new Framework Decision was about to be adopted, which only allowed to narrow the criminalization to cases related to a distortion of competition. ${ }^{20}$ Therefore, the limitation of criminalization of private sector corruption to cases likely to cause damage to the business entity is contrary to the 2003 Framework Decision [28].

In addition, neither of these restrictions of criminalization is foreseen in the 1999 Council of Europe Convention. Poland has no valid reservation as regards Art. 7 and 8 referring to the private sector corruption, ${ }^{21}$ which means that at present in order to fully implement this Convention the Polish criminal law should provide for a criminalization of the private sector corruption regardless of any additional conditions. The current criminalization is therefore an effect of the overlapping definitions of crimes laid down in supranational provisions and errors made by the Polish legislator when implementing these provisions into the national law. In result, a full implementation of supranational regulations has not been attained.

In fact, since the perpetrator may work in any business entity, operating in the public as well as in the private sector, the Polish law provides rather for an offence of economic bribery than typically private sector bribery as foreseen in supranational instruments [29]. It may be added that so far very few convictions based on the provisions referring to this types of corruptive behavior have been pronounced. ${ }^{22}$

\footnotetext{
${ }^{19}$ Pursuant to Article 2.1 of the Joint Action, the deliberate action of a person who, in the course of his business activities, directly or through an intermediary, requests or receives an undue advantage of any kind whatsoever, or accepts the promise of such an advantage, for himself or for a third party, for him to perform or refrain from performing an act, in breach of his duties, constitutes passive corruption in the private sector. Para. 2 provided that subject to Article 4(2), each Member State shall take the necessary measures to ensure that conduct of the type referred to in paragraph 1 is made a criminal offence. These measures shall at least cover such conduct which involves, or could involve, the distortion of competition, as a minimum within the common market, and which results, or might result, in economic damage to others by the improper award or improper execution of a contract.

${ }^{20}$ Pursuant to Art. 2.1(a) of the 2003 Framework Decision, passive corruption in the private sector is defined as directly or through an intermediary, requesting or receiving an undue advantage of any kind, or accepting the promise of such an advantage, for oneself or for a third party, while in any capacity directing or working for a private-sector entity, in order to perform or refrain from performing any act, in breach of one's duties. However, pursuant to para. 3 of the same article a Member State may declare that it will limit the scope of paragraph 1 to such conduct which involves, or could involve, a distortion of competition in relation to the purchase of goods or commercial services.

${ }^{21}$ Art. 7 provides as follows: "Each Party shall adopt such legislative and other measures as may be necessary to establish as criminal offences under its domestic law, when committed intentionally in the course of business activity, the promising, offering or giving, directly or indirectly, of any undue advantage to any persons who direct or work for, in any capacity, private sector entities, for themselves or for anyone else, for them to act, or refrain from acting, in breach of their duties". Pursuant to Art. 8 "Each Party shall adopt such legislative and other measures as may be necessary to establish as criminal offences under its domestic law, when committed intentionally, in the course of business activity, the request or receipt, directly or indirectly, by any persons who direct or work for, in any capacity, private sector entities, of any undue advantage or the promise thereof for themselves or for anyone else, or the acceptance of an offer or a promise of such an advantage, to act or refrain from acting in breach of their duties".

${ }^{22}$ In the average around 12 convictions per year in the years 2008-2011 (data of the National Criminal Register).
} 


\section{Criminalization of terrorism}

The harmonization has also taken place in regard to other types of criminal behavior. In particular it seems interesting to analyze the criminalization of terrorist activities. Before the process of internationalization as understood in this article, Polish criminal law had provided for a series of offences which might have been committed within terrorist activity, ${ }^{23}$ and was mostly in line [30] with the suppression conventions adopted by the UN to fight different types of manifestations of terrorism [31]. However, Polish law did not contain a definition of a terrorist act, even though ideas to adopt such a definition were discussed in the doctrine [32]. Such a definition was not added to the new Penal Code of 1997. Terrorism has hardly preoccupied the courts, the case-law has been scarce and reflected that in the absence of a legal definition courts referred to a linguistic meaning of terrorism [33].

As it known, a definition of a terrorist act has been provided for in a European Union instrument, namely the Council Framework Decision 2002/475/JHA of 13 June 2002 on combating terrorism. ${ }^{24}$ In order to fulfill the requirements set forth therein in 2004 Poland adopted a new definition of an act of terrorist character (Art. $115 \S 20$ PC). ${ }^{25}$ Pursuant to this provision, an offence of terrorist character is any act sanctioned with a penalty of deprivation of liberty, whose maximum statutory level is not less than 5 years, committed in order to: (i) seriously intimidate many persons (a population), (ii) unduly compel a public authority of the Republic of Poland or another state or international organization to perform or abstain from performing any act, or (iii) seriously destabilize or destroy the fundamental political, constitutional or economic structures of the Republic of Poland, another state or an international organization, as well as threatening to commit any of the acts [35]. This means that for a behavior to be considered an act of terrorist character, two conditions must jointly be fulfilled: the behavior must qualify as an offence of sufficiently serious

\footnotetext{
$\overline{23}$ The 1969 Penal Code provided for one offence which was called 'terrorist attack', consisting in violent assault on the life of a public or political activist, with the intent hostile to the People's Republic of Poland. However, also other provisions could have been used to penalize terrorist, i.e. referring to offences of sabotage, against life and health, or against public order. See [34].

${ }^{24}$ Pursuant to Art. 1 of the Framework Decision, "each Member State shall take the necessary measures to ensure that the intentional acts referred to below in points (a) to (i), as defined as offences under national law, which, given their nature or context, may seriously damage a country or an international organisation where committed with the aim of: - seriously intimidating a population, or - unduly compelling a Government or international organisation to perform or abstain from performing any act, or - seriously destabilising or destroying the fundamental political, constitutional, economic or social structures of a country or an international organisation, shall be deemed to be terrorist offences: (a) attacks upon a person's life which may cause death; (b) attacks upon the physical integrity of a person; (c) kidnapping or hostage taking; (d) causing extensive destruction to a Government or public facility, a transport system, an infrastructure facility, including an information system, a fixed platform located on the continental shelf, a public place or private property likely to endanger human life or result in major economic loss; (e) seizure of aircraft, ships or other means of public or goods transport; (f) manufacture, possession, acquisition, transport, supply or use of weapons, explosives or of nuclear, biological or chemical weapons, as well as research into, and development of, biological and chemical weapons; (g) release of dangerous substances, or causing fires, floods or explosions the effect of which is to endanger human life; (h) interfering with or disrupting the supply of water, power or any other fundamental natural resource the effect of which is to endanger human life; (i) threatening to commit any of the acts listed in (a) to (h)".

${ }^{25}$ Act of 16 April 2004 amending the PC and other statutory acts, O.J. No 83, item 889.
} 
character, confirmed by a high sanction, and it must be carried out with a specific intent.

Such a method of implementation of the 2002 Framework Decision seems quite unique in comparison to other EU Member States, which usually tend to follow more closely the model set forth in the Framework Decision [36]. The choice of the implementation method itself would not be controversial if the new provision was in line with the EU law requirements. However, it seems that the Polish definition does not fully comply with this obligation. On the one hand the definition is subject to criticism for being too narrow. Some of the prohibited behaviors mentioned in the Framework Decision are not covered by the Polish definition, for instance "research into, and development of, biological and chemical weapons" listed in Art. 1 (1f) of the Framework Decision [37]. In addition, some authors argue that since the legislator decided to define the notion of terrorism by using the description of the purposes of the criminal behavior, the Code should not make reference to the severity of punishment [38]. The penalty limit may unjustly exclude acts which should qualify as terrorism out of the scope of criminalization. On the other hand, this definition has been criticized for being too wide in relation to the definition laid down in the Framework Decision. Indeed, in Polish law the responsibility for an act of terrorist character is related to the commission of any type of offence, provided it has been undertaken with a view to pursuing any of the purposes enumerated in the subject provision and remains within the penalty limit. It is true that the Framework Decision puts forward only a minimum standard and Member States are free to qualify further behaviors as terrorist. This must, however, be done reasonably and in the light of the ultima ratio principle. The Polish definition does not take into account a further limitation contained in the Framework Decision, according to which prohibited behaviors are considered terrorist if, "given their nature or context", they "may seriously damage a country or an international organization". This requirement, if included into the Polish criminal law, could limit unjustified qualification of some behaviors as terrorism.

Interestingly, the European Commission considers that Poland did not implement Art. 1 of the Framework Decision properly. It indicates that the technique used to define terrorist offences raises some concerns as Poland only defines terrorist intent [39]. This position suggests that Polish law is in fact undercriminalized and it should also include a catalogue of offences as well as the further limitation set forth in Art. 1 of the Framework Decision.

From a practical point of view, commission of an act of terrorist character allows an increase of the punishment, following the rules referring to the multiple relapse into crime, which means that a perpetrator of an act of terrorist character may be subject to a penalty mandatorily exceeding the lower statutory level and optionally up to the upper statutory level increased by half.

\section{Criminalization of core crimes}

The process of internationalization of the Polish criminal law also consisted in harmonization of the national provisions with international criminal law. Despite the fact that the core crimes were criminalized by Poland directly in the 1997 PC [40], in 2010 the government prepared a draft proposal to amend the Penal Code. It 
submitted that seemingly the Code did not contain all of the elements of definitions of core crimes as provided for in the Rome Statute, in particular Art. 7 of the Rome Statute. A series of new provisions was adopted. ${ }^{26}$ Some of the changes, the purpose of which was to add precision to the existing provisions, are to be assessed positively [41]. However other extensive changes may be subject to justified criticism, in particular due to ambiguous definitions of prohibited behaviors, containing terminology foreign to the Polish law and even sometimes to the Statute [42]. For instance, Art. 7 of the Rome Statute refers to a 'widespread or systematic attack directed against any civilian population', whereas new Art. 118a of the PC mentions 'massive attack against a population'. The relation between these terms is not explained in the justification of the draft project [43]. Also, the PC refers to "rape or other violations of a person's sexual freedom with the use of violence, unlawful threat or deceit", but it is not clear whether these terms cover "sexual slavery, enforced prostitution, forced pregnancy, enforced sterilization, or any other form of sexual violence of comparable gravity" mentioned in Art. 7(1 g) of the Statute. Most of these new terms have not been explained in the law, the only clarification that was adopted directly in the Code is the definition of 'slavery' (Art. $115 \S 23 \mathrm{PC}$ ). ${ }^{27}$ As Gardocki justly points out, in the course of the process of implementation, the provisions of the ICC Statute have not been directly, in their totality, included in the PC, but at the same time, the Polish implementing provisions have not been adjusted to the language used in the ICC Statute. The result is a mixture of terms which may be very difficult to interpret [44].

\section{Modernization of Polish criminal law}

As it has been mentioned, the impact of globalization on the Polish criminal law goes beyond internationalization and refers to the unifying force of globalization. Similar types of socially condemned behaviors occur in many countries which are later qualified as criminal offences. Stalking is a good example here. Criminal harassment is not subject to any international legal regulation. It seems unlikely to qualify under any of the categories of the rationale for international criminalization mentioned by M. Ch. Bassiouni [45]. However, the criminalization of stalking is more and more widespread as individuals in different countries tend to reproduce dysfunctional - and consequently recognized as criminal - behaviors.

Poland is no exception here. In the Polish criminal law stalking was criminalized in June 2011, mainly due to some stalking cases discussed in the media. The definition of the offence is quite ambiguous and contains many elements the occurrence of which depends on the judge's personal assessment ${ }^{28}$ (eg. how much harassment is enough to qualify as 'persistent', when harassment is justifiably threatening, when violation of privacy becomes 'substantial') [46]. To some extent such a definition is understandable as it is difficult to properly describe in legal terms the features of this

\footnotetext{
$\overline{26}$ Act of 20 May 20120, O.J. No 98, item 626, came into force on 8 September 2010.

${ }^{27}$ Pursuant to this definition, slavery constitutes a state of dependence, in which a person is treated like a property.

${ }^{28}$ Pursuant to Art. 190a para. 1 of the PC, is subject to a penalty of deprivation of liberty up to 3 years whoever persistently harasses another person or a next of kin to this person which causes this person to justifiably feel threatened or substantially violates this person's privacy.
} 
multi-faced phenomenon, even though undesirable from the point of view of quality of criminal law. In any case, however, clearly the intention of the legislator was to penalize a certain set of acts, following examples of numerous states which criminalize it. The justification of the draft law submitted to the Parliament stated that all the American states, as well as 9 European states criminalize stalking [47].

The influence of globalization may also be detected in the amendments introduced to the Polish system of additional penal measures. Polish criminal law recognizes main penalties and additional measures. The latter are applied in specifically defined circumstances with regard to perpetrators of specific offences. A series of new measures regarding perpetrators of sexual offences committed against a minor was adopted in $2005 .^{29}$ Some of these measures, referring inter alia to the prohibition of the exercise of certain professions [48] may be applied permanently, ie. for an undetermined duration and may never be waived under any circumstances nor their register may be subject to cancellation. These provisions are criticized for being nonhumanitarian [49]. No famous cases of pedophile offences have occurred in Poland, however the growing condemnation of pedophile activity affected Poland as it affected other countries.

\section{Discussion}

The Polish criminal law has certainly transformed under the influence of globalization, more particularly the processes of internationalization and modernization stemming from globalization. The purpose of this study was to asses the extent of this transformation using a number of illustrative examples. To sum up, it suffices to say that both the general and special part of criminal law have been changed under international influence. Previously focused exclusively on internal interests, internationalized Polish criminal law now offers protection to interests of foreign states and international organizations as well as to new types of private bodies. Most of the modifications undertaken concern the scope of criminalization which was largely extended to cover new types of criminal behaviors.

Having described the extent of the transformation, one should reflect on the quality of implementing legislation. Second, the issue of the need of change must be addressed.

Considering the first issue, in my view, the quality of implementing legislation, frequently adopted under the threat of passing deadlines, is questionable. Methods of implementation used by the Polish legislator have varied, but it is hard to find a rule that would explain the choice of a method applied to implement a supranational provision. In particular it seems that the choice of a method was in no relation to the fact that the treaty provision was novel or not to the national law.

Occasionally, the method of direct transposition was applied - supranational provisions were directly adopted in the Penal Code. However, then a problem of translation of foreign provisions occurred. There was also a problem of understanding

\footnotetext{
${ }^{29}$ Act of 27 July 2005, O.J. No 163, item 1363, entered into force on 26 September 2005. On this reform see $[50]$.
} 
and, consequently, practical application of foreign institutions within the Polish legal system. At other times, supranational provisions were indirectly transposed. This means that an attempt was made to decode the essence of a set of provisions or a legal institution and to fit it into the national system in the best possible manner. But the choice of such a method entailed a complication with the adaptation of foreign institutions and foreign provisions to the Polish law. The features of the offence as defined in the Polish law have not necessarily reflected the elements of the definition of the offence in international or supranational instruments. In addition, albeit rarely, assimilation clauses were applied, under which the Polish provisions should be applied 'respectively' to transnational cases. The meaning of this formula is unclear and therefore the courts will have problems with its proper application. To sum up, there was no coherent reflection as to what technique of harmonization should be used by the Polish legislator and why. Also, the terminology used to translate foreign legal terms was diverse and not necessarily adapted to the Polish law. The same applies to changes adopted within the process of modernization, in particular the enactment of new crimes. As proven above, elements of new crimes are not adjusted to the traditional national definitions of offences and they contain unclear terms.

The poor quality of legislation may generate several types of problems. Firstly, looking from a supranational perspective, often the level of harmonization attained by Poland is not satisfactory, even though it may be higher than that obtained by 'old' Member States of respective international organizations. Furthermore, the lack of harmonized mechanisms may heavily impair international cooperation in fighting against crime, which obviously is not desirable and contradicts the very purpose of supranational legal instruments.

More importantly, at a domestic level, poor quality of new or harmonizing legislation, using unclear terms to define offences, may be questioned in the light of the constitutional requirements of nullum crimen sine lege. The principle of maximum certainty as an element of the principle of legality expressed by the nulla crimen maxim, obliges the legislator to use the clearest terms possible when defining a prohibited behavior so that all persons are aware of what is allowed and what is not [51]. As A. Ashworth indicates, "a person's ability to know of the existence and extent of a rule is fundamental" [52]. When the legislator uses unclear terminology, it in fact forces the courts to define the prohibition on case-to-case basis, which is not in line with the Constitution.

Furthermore, the poor quality legislation may hinder application of transposed provisions for practical reasons. For instance, accessible data indicate that convictions for many of the newly adopted crimes are rather unique. ${ }^{30}$ In my view this is due to three factors. Firstly, the lack of awareness on the part of the law enforcement - the new crimes are not familiar to the law enforcement agencies, which have enough work when dealing with traditional crimes. Secondly, the lack of know-how and funding. The detection and prosecution of new crimes (in particular financial ones) require skills which the police officers and prosecutors do not necessarily possess. In

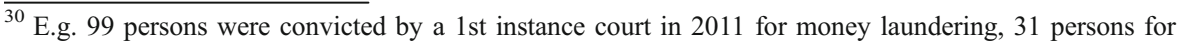
corruption in the private sector, out of 416,637 convicted in total. See [54].
} 
order to prove the crime was actually committed they must appoint an expert, who is expensive and difficult to find. ${ }^{31}$ Thirdly, the general public's lack of awareness or interest in prosecution. People are not aware of the new crimes or they have no interest in their prosecution. ${ }^{32}$

In my view the extent of the change of the law in action following the change of the law in books, i.e. the Polish criminal legislation induced by globalization, is unsatisfactory. It rather seems that the modifications were superficial only and did not imply an actual implementation of newly introduced institutions and provisions. What we obtain in return is a so-called symbolic criminalization [53], free of any real importance. This issue certainly requires further and more systematic analysis beyond the framework of this paper.

And eventually, there is a second, larger problem related to the transformation of Polish criminal law induced by globalization, referring to the need of change.

It should be stated at the outset that the internationalization has not been a fully voluntary process. Polish legislator adopted the new laws not because it believed they could address certain internally identified needs. All of the early adopted modifications, as a part of the process of internationalization of Polish criminal law, were necessary from the political point of view as they were one of the main conditions of the Polish membership in international organizations. At the time Poland had no other choice but to change its legislation, including criminal law, according to the requirements laid down in supranational provisions. Afterwards, it seems that Poland wanted to be regarded positively and therefore fulfilled its obligations stemming from supranational instruments willingly. So it was the political choice made at the beginning of the $90 \mathrm{~s}$, when Poland decided to aspire for membership in the Western organizations, that has driven the legislative transformation. As Szarek-Mason states in the context of the EU accession process, "one of the most prominent features of the 2004 enlargement process was conditionality, defined as the linking, by a state or international organisation, of perceived benefits to the fulfillment of certain conditions" [55] and goes on by saying "The EU used conditionality as a tool to influence the content of internal policies of candidate countries. The CEE countries were expected to meet all the conditions and were not able to decide on the content of conditions" [56]. In this way Polish criminal law has become, to some extent, a hostage of politics. There was no question whether the change was necessary as it was politically justified.

I would not argue that in the era of globalization national legislators should strive to preserve the distinctive national character of criminal law as I do not believe that the distinctiveness constitutes a value in itself. ${ }^{33}$ However, I think that the national

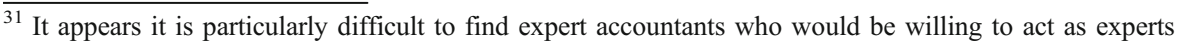
within criminal proceedings while they may earn a lot more in the private sector that the state has to offer. The difficulties in finding qualified experts and low level of opinions given by experts, related by many to the low fees for experts foreseen in law, are the main reasons behind the conceptual works over the normative framework referring to appointment of experts, initiated by the Ministry of Justice. No draft of legal act was submitted to the Parliament yet.

${ }^{32}$ This remark applies in particular to the private sector which e.g. has no interest in prosecuting private sector corruption. This negative attitude would translate a very low number of cases of private sector corruption detected in Poland - no cases during the first couple of years after the criminalization has been adopted (2003) and a few cases per year in recent years.

${ }^{33}$ Many positive changes, in particular in Polish procedural criminal law have been adopted under the foreign influence, for instance due to the case-law of the European Court of Human Rights. See [57].
} 
criminal law should constitute an internally coherent system, for its coherence inter alia assures effective prosecution of crimes. It should also follow the constitutional principles of good legislation. Faced with the challenges of internationalization Polish legislator seemed to forget about these requirements.

This is particularly manifest when it comes to criminalization. To a large extent the internationalization and modernization have not been accompanied by any rationales for adoption of new criminalizations. In principle, adoption of a new offence should be aimed at suppressing newly identified harmful behaviors, but almost no studies have been carried out to verify if these behaviors were really occurring in Poland. ${ }^{34}$ When it comes to internationalization, the need to implement an international convention or an EU legal act has been sufficient to justify criminalization. Hence, there have been no considerations referring to the ultima ratio principle when introducing new types of offences. The criminal prohibition resulting from a treaty or EU law has been enough. Apparently, domestic reflection on directions of Polish criminal policy has not been required as its aims have been defined by the necessities of internal or international politics. Indeed, due to constraints of the process of internationalization and to modernization as of now Poland has no coherent criminalization policy; criminalization takes place on a case-to-case basis, depending on the obligations resulting from supranational law or current mass media interest. ${ }^{35}$ Regrettably, it seems that it is not specifically Polish disease [59] and as such it will not be cured easily.

It would be naïve to complain about the necessities of politics and the consequent process of internationalization. The new crimes will not be abolished as that would be contrary to the international obligations of Poland and thus politically unacceptable. Having said that, the Polish legislator could have been much more active and seek to achieve at the same time a better quality of legislation and a higher level of compliance with supranational provisions. What can be done today to address existing deficiencies? For start, thorough studies could be carried out to assess the effectiveness of current criminalizations and to project desirable changes in this respect, aimed at assuring a greater extent of the internal coherence of the Polish criminal law and a better compliance with international instruments. And later, a revised legislation could be adopted, this time not under the pressure of time or international bodies.

Open Access This article is distributed under the terms of the Creative Commons Attribution License which permits any use, distribution, and reproduction in any medium, provided the original author(s) and the source are credited.

\section{References}

1. Zoll, A. (2011). Konstytucyjne aspekty prawa karnego. In T. Bojarski (Ed.), System prawa karnego, vol. II. Źródła prawa karnego, $223 \mathrm{f}$.

2. Held, D. (2000). The changing contours of political community, In R. Ericson, N. Stehr (Eds.), Governing Modern Societies 42.

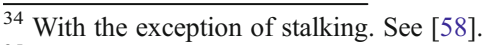

35 The issue of penal populism and its relations with globalization and more particularly changes of social and cultural patterns caused by globalization should be considered in this respect. However, this would certainly go beyond the limited framework of this paper.
} 
3. Mueller, G. W. (2001). Transnational crime: definitions and concepts. In P. Williams, \& D. Vlassis (Eds.), Combating transnational crime 13.

4. Boister, N. (2003). Transnational Criminal Law? EJIL, 14(5), $953 \mathrm{f}$.

5. Marek, A. (2006). Prawo karne, 19 f; Wróbel, W., Zoll, A. (2010). Polskie prawo karne. Cześć ogólna $70 \mathrm{f}$.

6. Bassiouni, M. C. (1996). An Appraisal of the Growth and Developing Trends of International Criminal Law. In J. Dugard, C. van den Wyngaert (Eds.), International criminal law and procedure 85.

7. Twining, W. (2009). General Jurisprudence 250-251.

8. Gerecka-Żołyńska, A. (2009). Internacjonalizacja współczesnego procesu karnego w Polsce.

9. Moveyval reports on evaluation of Polish legislation, http://www.coe.int/t/dghl/monitoring/moneyval/ Countries/Poland_en.asp (accessed on 1 Dec 2012), in particular the Third Round Detailed Report on Poland. Anti-Money Laundering and Combating the Financing of Terrorism, 22.11.2007 and two following Progress Reports of 2008 and 2010.

10. Boister, N., [4] 985; Bohlander, M. (2008). The General Part: Judicial Developments. In M.C. Bassiouni (Ed.), International Criminal Law. $3^{\text {rd }}$ Ed. Vol. III. International Enforcement $517 \mathrm{f}$.

11. Agreement between the Government of the Republic of Poland and the United Nations on the Enforcement of Sentences of the International Criminal Tribunal for the Former Yugoslavia, 18 Sept 2008, http://www.icty.org/x/file/Legal\%20Library/Member_States_Cooperation/enforcement_ agreement_poland_18_09_08_en.pdf (accessed 1 September 2012).

12. Marston Danner, $\bar{A} \cdot(\overline{2} 00 \overline{8})$. Joint criminal enterprise. In M. C. Bassiouni (Ed.), International criminal law. 3rd Ed. Vol. III. International Enforcement $483 \mathrm{f}$.

13. Wallach, E., \& Marcus, I. M. (2008). Command responsibility. In M. C. Bassiouni (Ed.), International criminal law. 3rd Ed. Vol. III. International enforcement 474.

14. Gardocki, L. (2011). Nowelizacja przepisów o przestępstwach przeciwko pokojowi, przeciwko ludzkości i przestępstw wojennych, CzPKiNP 114.

15. Poland: Phase 2. Report on the Application of the Convention on Combating Bribery of Foreign Public Officials in International Business Transactions and the 1997 Revised Recommendation on Combating Bribery in International Business Transactions, 18 January 2007, OECD, 68, http://www.oecd.org/daf/briberyininternationalbusiness/anti-briberyconvention/ 38030514.pdf (accessed 12 September 2012).

16. Bojarski, T. (2011). Zasady obowiązywania ustawy karnej. In T. Bojarski (Ed.), System prawa karnego. Vol. II. Źródła prawa karnego 552. On the meaning of these principles in international law: Cassese, A. (2003) International Criminal Law $277 \mathrm{f}$.

17. Sakowicz, A. (2011). In M. Królikowski, R. Zawłocki (Eds.), Kodeks karny. Część ogólna. Tom II. Komentarz do art. 32-116, 2nd ed. 1037-1038; Raglewski, J. (2012). In A. Zoll (Ed.), Kodeks karny. Część ogólna. Tom I. Komentarz do art. 1-116 k.k. 4th ed., 1294.

18. Sejm file No 2013, 24 September 2003.

19. Sakowicz, A. [17] 1048-1050; Raglewski, J. [17] 1302.

20. Sakowicz, A. [17] 1053.

21. Nowak, C. (2008). Korupcja w polskim prawie karnym na tle uregulowań międzynarodowych 20-63.

22. Judgment of the Supreme Court of 3 July1970, VI KZP 27/70, PiP 1970 No 10, 629.

23. Nowak, C., [21], 359-369.

24. Sejm file No 869, 10 September 2002, 18-19.

25. Nowak, C. (2008). O pojęciu “osoba pełniąca funkcję publiczną”. In J. Jakubowska-Hara, C. Nowak, J. Skupiński (Eds.), Reforma prawa karnego - propozycje i komentarze 170-183; Majewski J. (2012). In A. Zoll (Ed.), Kodeks karny. Część ogólna. Tom I. Komentarz do art. 1-116 k.k. 4th ed. 1426 -1434.

26. Nowak, C., [21], 390-391.

27. Detailed analysis of these features of offences Iwański M. (2009). Nowa postać łapownictwa gospodarczego (po nowelizacji art. 296a § 1 k.k.), Państwo i Prawo No 10, 70-82.

28. Nowak, C. (2012). The europeanisation of Polish substantive criminal law: How the european instruments influenced criminalisation in Polish law. New Journal of European Criminal Law, 3, 371-373.

29. Nowak, C., [21], 392.

30. Aleksandrowicz, T. R. (1988). Pojęcie czynu o charakterze terrorystycznym „de lege lata” i ,de lege ferenda" (Wybrane zagadnienia). Problemy Praworzadności No 10, 24.

31. Currie, R. J. (2010). International and Transnational Criminal Law, $343 \mathrm{f}$.

32. Aleksandrowicz, T. R. (2004). [26], 28; Indecki, K., Kryminalizacja aktu terrorystycznego - zagadnienia wybrane, ACL FI, vol. 67, 24.

33. Judgment of Supreme Court of 26 June 2003, V CKN 432/01, OSNS 2004 No 9, item 145. Also see Wiak K. [24], 225-226. 
34. Bafia, J., Mioduski, K., \& Siewierski, M. (1971). Kodeks karny. Komentarz 294-297; Wiak, K. (2009). Prawnokarne środki przeciwdziałania terroryzmowi 216, in English: Wiak, K. (2012). Terrorism and Criminal Law 127-128. On 1997 Penal Code see Filar, M. (2002). Terroryzm - problemy definicyjne oraz regulacje prawne $w$ polskim prawie karnym $w$ świetle prawa międzynarodowego i porównawczego. In V. Kwiatkowska-Darul (Ed.), Terroryzm 27-36.

35. See more on this: Górniok, O. (2004). Przestępstwo o charakterze terrorystycznym w art. $115 \S 20$ k.k., Przeglad Sadowy No 10, 3-11.

36. See more on this: Wiak K. [24] 231-233.

37. Zielińska, E. (2004). Uwagi do projektu ustawy o zmianie ustawy-Kodeks karny oraz niektórych innych ustaw (druk sejmowy 2407) 2.

38. Rybak-Starczak, A. (2004). Środek do osiagnięcia celu, Rzeczpospolita, 4 November, 4.

39. Report from the Commission based on Article 11 of the Council Framework Decision of 13 June 2002 on combating terrorism, COM (2007) 681 final, 6.11.2007, 5.

40. Flemming, M., \& Wojciechowska, J. (1999). Zbrodnie wojenne. Przestępstwa przeciwko pokojowi, państwu i obronności. Rozdział XVI, XVII i XVIII Kodeksu karnego. Komentarz, 15-124. Gardocki, L. [13], 115.

41. Gardocki, L. [13], 115-116.

42. Budyn-Kulik, M. (2010). Commentary to Art. 118 a of the Penal Code, LEX.

43. Wróbel, W. (2010). Opinia w sprawie rządowego projektu ustawy o zmianie ustawy - Kodeks karny, ustawy - Przepisy wprowadzające Kodeks karny, ustawy - Kodeks postępowania karnego oraz ustawy o Policji, Sejm file No 2387, 4.

44. Gardocki, L. [13], 116.

45. Bassiouni, M. C. (2008). International crimes: the ratione materiae of international criminal law. In M. C. Bassiouni (Ed.), International criminal law. Vol. I, 133

46. Golonka, A. (2012). Uporczywe nękanie jako nowy typ czynu zabronionego. Państwo i Prawo, No 1, 88-100.

47. Sejm file No 3553, 27 October 2010, 1-2.

48. Stefański, R. A. (2007). Środek karny zakazu prowadzenia działalności związanej z wychowaniem, leczeniem, edukacją małoletnich lub opieką nad nimi. Prokuratura i Prawo, No 7-8, 42 f.

49. Mozgawa, M. (2012). Komentarz do art. $106 a$ k.k., LEX.

50. Szyrmer, S. (2006). Nowelizacja prawa karnego w świetle ustawy z dnia 27 lipca 2005 r. o zmianie ustawy - Kodeks karny, ustawy - Kodeks postępowania karnego i ustawy - Kodeks karny wykonawczy, CzPKiNP, No 1, $53 \mathrm{f}$.

51. Zoll, A., Wróbel, W. [5], 101-102.

52. Ashworth, A. (2003). Principles of Criminal Law, 77.

53. Gardocki, L. (1990). Zagadnienia teorii kryminalizacji, $178 \mathrm{f}$.

54. Ministry of Justice, http://bip.ms.gov.pl/pl/dzialalnosc/statystyki/ (accessed August 1, 2012).

55. Szarek-Mason, P. (2010). The European Union's Fight Against Corruption: The Evolving Policy Towards Member States and Candidate Countries, 135.

56. Szarek-Mason P. [45], 136.

57. Dynia, E., \& Kłak, C. P. (Eds.) (2005). Europejskie standardy ochrony praw człowieka a ustawodawstwo polskie; Błachnio-Parzych, A., Kosonoga, J. (2009). Rzetelny proces karny w orzecznictwie Sądu Najwyższego. In P. Wiliński (Ed.), Rzetelny proces karny $233 \mathrm{f}$.

58. Sejm file No 3553, 27 October 2010, 2 [47].

59. Husak, D. (2008). Overcriminalization. 